\title{
Pine Tree Substrate, Nitrogen Rate, Particle Size, and Peat Amendment Affect Poinsettia Growth and Substrate Physical Properties
}

\author{
Brian E. Jackson ${ }^{1,4}$, Robert D. Wright ${ }^{2}$, and Michael C. Barnes ${ }^{3}$ \\ Department of Horticulture, Virginia Polytechnic Institute \& State University, \\ 301 Saunders Hall, Blacksburg, VA 24061
}

Additional index words. container substrate, Euphorbia pulcherrima, loblolly pine, Pinus taeda, peat substitute, pine chips, potting media, root medium, wood substrate, WoodGro ${ }^{\mathrm{TM}}$

\begin{abstract}
Prestige' poinsettias (Euphorbia pulcherrima Willd. Ex Klotzsch) were grown at different fertilizer rates in three pine tree substrates (PTS) made from loblolly pine trees (Pinus taeda $\mathrm{L}$.) and a peat-based control. Pine tree substrates were produced from pine trees that were chipped and hammer-milled to a desired particle size. Substrates used in this study included peat-lite (PL), PTS produced with a $2.38-\mathrm{mm}$ screen (PTS1), PTS produced with a 4.76-mm screen (PTS2), and PTS produced with a 4.76-mm screen and amended with $25 \%$ peatmoss (v/v) (PTS3). Initial and final substrate physical properties and substrate shrinkage were determined to evaluate changes over the production period. Poinsettias were grown in 1.7-L containers in the fall of 2007 and fertilized at each irrigation with $100,200,300$, or $400 \mathrm{mg} \cdot \mathrm{L}^{-1}$ nitrogen $(\mathrm{N})$. Shoot dry weight and growth index were higher in $\mathrm{PL}$ at $100 \mathrm{mg} \cdot \mathrm{L}^{-1} \mathrm{~N}$ but similar for all substrates at $300 \mathrm{mg} \cdot \mathrm{L}^{-1} \mathrm{~N}$. Bract length was generally the same or longer in all PTS-grown plants compared with plants grown in PL at each fertilizer rate. Postproduction time to wilting was the same for poinsettias grown in PL, PTS1, and PTS3. Initial and final air space was higher in all PTSs compared with PL and container capacity (CC) of PTS1 was equal to PL initially and at the end of the experiment. The initial and final CC of PTS2 was lower than PL. The incorporation of $25 \%$ peat (PTS3) increased shoot dry weight and bract length at lower fertilizer rates compared with $4.76 \mathrm{~mm}$ PTS alone (PTS2). Substrate shrinkage was not different between PL and PTS1 but greater than shrinkage with the coarser PTS2. This study demonstrates that poinsettia can be successfully grown in a PTS with small particles $(2.38-\mathrm{mm}$ screen) or a PTS with large particles $(4.76-\mathrm{mm}$ screen) when amended with $25 \%$ peatmoss, which results in physical properties (CC and air space) similar to those of PL.
\end{abstract}

Poinsettia is the number one selling potted plant produced and sold in the United States and the preferred substrates for their production are peat-based (Hidalgo and Harkess, 2002). Peatmoss is also the preferred substrate for the production of most all other greenhouse crops. The production of greenhouse crops has increased over the past

Received for publication 17 July 2008. Accepted for publication 14 Aug. 2008.

This research was funded in part by the American Floral Endowment, Virginia Agricultural Council, the Virginia Nursery and Landscape Association, and the Virginia Tobacco Commission. Plant material donated by Ecke Ranch, Yoder Brothers, Inc., Barberton, $\mathrm{OH}$.

Technical assistance of Breanna Rau and Joyce Shelton is gratefully acknowledged.

Use of trade names does not imply endorsement of the products named nor criticism of similar ones not mentioned. The cost of publishing this paper was defrayed in part by payment of page charges.

${ }^{1}$ Graduate Research Assistant.

${ }^{2}$ Professor.

${ }^{3}$ Research Technician

${ }^{4}$ To whom reprint requests should be addressed; e-mail jacksonb@vt.edu decade (2007 Floriculture and Nursery Crops Yearbook, 2007), thereby increasing the use and demand of peat. Although world peat reserves are significant, the question of limiting peat extraction to avoid the destruction of these fragile natural environments (nonrenewable peat bogs) is of increasing concern among environmental, scientific, private, and governmental agencies in Europe (Carlile, 2004; Clark, 2008; Riviere et al., 2008; Robertson, 1993). In the United Kingdom, for example, these concerns have prompted governmental regulations on the use of peat and set target deadlines of $90 \%$ peat replacement by 2010 (Holmes, 2008). In response to the regulations, investigation of numerous peat alternatives in Europe has been conducted, but the acceptance and use of these materials has been gradual as a result of the continued low cost of peat (Schmilewski, 2008). There are no regulations or governmental mandates to decrease the use of peat (mined and shipped from Canada) here in the United States, but recent increases in fuel (transportation) costs have led to the increasing cost of peat substrates and therefore have resulted in greater interest in less expensive and locally available peat substitutes. Re- searchers are addressing the increasing cost of peat by investigating renewable alternative substrates from other organic materials that can offer equal growth performance as that of peat but at a cheaper cost.

Wang and Blessington (1990) reported similar growth of poinsettia (number of branches and bracts, days to flower, and overall plant grade) in a substrate derived from composted cotton burrs compared with plants grown in a peat:pine bark substrate. Other works demonstrating the use of composted organic materials ( $\mathrm{Ku}$ et al., 1998; Papafotiou et al., 2004) have been reported for poinsettia production.

Research has also been conducted on using wood and plant-based substrates for greenhouse crop production. Lang (1997) and Webber et al. (1999) reported results with a substrate composed of noncomposted ground kenaf (Hibiscus cannabinus L.) plants to produce poinsettia and periwinkle (Vinca minor L.) with equal size and quality to plants grown in peat-based substrates. Wood shavings of fir (Pseudotsuga menziesii Mirb.) and redwood (Sequoia sempervirens D. Don) trees (Criley and Watanabe, 1974) and sawdust (derived from hardwood and softwood tree species) have been investigated for the production of carnations (Dianthus caryophyllus L.; Starck and Lukaszuk, 1991), chrysanthemums (Chrysanthemum morifolium Ramat.; Scott and Bearce, 1972; Still et al., 1972), and other potted foliage plants (Worrall, 1981) with results compared with peat-based substrates.

The problem with most of the aforementioned materials is the lack of uniformity that often exists with composts and wood waste materials like sawdust and wood shavings. The lack of substrate consistency and insufficient quantities of these waste materials is a problem for long-term and sustained use as a major substrate, especially for large production operations. In response, researchers have begun testing wood-based substrates that are specifically produced for use as container substrates instead of using wood waste and byproduct materials. Research in Europe has been conducted for over two decades on the development of horticultural substrates composed of wood (Gumy, 2001; Raviv and Lieth, 2008; Schilling, 1999; Nazim Gruda, personal communication, 2007). Gerber et al. (1999) demonstrated that geranium (Pelargonium $\times$ hortorum L.H. Bailey) could be grown in a $100 \%$ wood fiber substrate with similar growth to plants grown in peat if they were irrigated and fertilized more often than the plants grown in peat.

More recently, a pine tree substrate (PTS) derived from delimbed loblolly pine trees and referred to as WoodGro ${ }^{\mathrm{TM}}$ (WoodGro LLC., Blacksburg, VA) was developed. Successful production has been reported on numerous woody (Jackson et al., 2008; Wright and Browder, 2005; Wright et al., 2006) and herbaceous species (Wright et al., 2008). Fain et al. (2008) and Boyer et al. (2008) reported successful bedding plant growth in PTSs derived from loblolly pine trees 
(including limbs, bark, and needles) compared with plants grown in $100 \%$ pine bark (PB).

Nelson (2003) in describing the desirable properties of substrates for greenhouse crops noted the importance of organic matter stability and carbon $(\mathrm{C})$ :nitrogen $(\mathrm{N})$ ratio. The high $\mathrm{C}: \mathrm{N}$ ratio of wood substrates, resulting in the tie-up of $\mathrm{N}$ resulting from microbial immobilization, and wood substrate stability (decomposition) over time have been major concerns of researchers and growers. Researchers have shown, however, that reduced plant growth in wood substrates is generally only a problem when fertility levels (primarily $\mathrm{N}$ ) are near the lower limits for optimal plant growth and development (Hicklenton, 1983). Wright et al. (2008) have shown that chrysanthemums can be successfully grown in a $100 \%$ PTS with an additional 100 ppm N compared with plants grown in a commercial peat substrate. Other works by Still et al. (1972), Gruda and Schnitzler (1999), Wright et al. (2006), and Jackson et al. (2008) have shown that growth of plants produced in wood substrates is equal to plants produced in peat and PB substrates when higher fertilizer rates are supplied. Stability of wood substrates over time has been reported to range from $36 \%$ volume loss over 15 months (Fischer et al., 1993) to 50\% volume loss over 51 weeks (Meinken and Fischer, 1997) during crop production. The wood substrates used in these reports were wood fiber (so named as a result of their manufacturing process and physical properties) and were derived from a mixture of various tree species, primarily spruce (Picea abies L.). Jackson and Wright (2008) and Jackson et al. (2008) report no significant visual substrate shrinkage or decomposition of PTS during greenhouse and nursery crop production and Fain et al. (2008) noted less shrinkage of a PTS than a peat substrate during a 5-week greenhouse trial. Changes brought about by shrinkage are undesirable because containers may need to be topped off with substrate before distribution (sell). Furthermore, substrate shrinkage usually increases container capacity (CC) and decreases air space (AS) of substrates during production (Aendekerk, 2001).

In addition to substrate stability and $\mathrm{C}: \mathrm{N}$ ratio, the successful production of poinsettia (and all greenhouse crops) requires having a substrate with other desirable physical and chemical properties that can promote and sustain healthy plant growth. Previous plant growth experiments with PTS have been conducted on various substrate screen sizes (with a range of physical properties), including $4.76 \mathrm{~mm}$ (Wright et al., 2008) and $6.35 \mathrm{~mm}$ (Fain et al., 2008; Jackson et al., 2008; Wright et al., 2006) with plant growth being similar to plants grown in peat or PB. Researchers have shown that PTS can be constructed to produce a wide range of physical properties such as AS and waterholding capacities (WHC) that are similar to commercial peat substrates (Saunders et al., 2006). To achieve this, PTS is hammer- milled for a longer period of time to further reduce the particle size. The longer processing requires additional time, energy, and labor thereby increasing the cost of PTS production. Incorporation of peat, $\mathrm{PB}$, or other amendments may improve physical properties of larger PTS particle sizes to create a desired substrate for greenhouse crop production at a cheaper cost (less grinding time of PTS in a hammer mill). Browder et al. (2006) has shown that the incorporation of peat in PTS improves plant growth at lower fertility rates compared with $100 \%$ unamended PTS.

Research has not been reported on poinsettia production in PTS or the evaluation of plant growth in different particle sizes of PTS under different fertility regimes. Results from a preliminary unpublished study in 2005 indicated that poinsettia can be grown in PTS with comparable growth to plants grown in peat-lite (PL) if the fertilizer solution $\mathrm{N}$ concentration was increased from $200 \mathrm{mg} \cdot \mathrm{L}^{-1} \mathrm{~N}$ to $300 \mathrm{mg} \cdot \mathrm{L}^{-1} \mathrm{~N}$. This experiment is a follow up to the study mentioned previously with the incorporation of particle size and peat amendment as additional parameters for evaluation. The effect of peat incorporation into PTS needs to be further investigated as a way to improve physical and chemical properties of PTS during crop production. Potential shrinkage of PTS during crop production and how it may affect substrate physical properties has not been reported. Determination of PTS stability over time under fertilized container conditions is critical because the change in physical properties during crop production can directly affect irrigation needs and plant growth. Based on these unanswered questions, the objectives of this research were to determine the effect of 1) fertilizer rate; 2) substrate particle size; and 3) peat amendment on growth and floral quality and on postproduction time to wilting of poinsettias.

\section{Materials and Methods}

The substrates used in this experiment were: 1) PTS produced with a $2.38-\mathrm{mm}$ screen (PTS1); 2) PTS produced with a 4.76-mm screen (PTS2); 3) PTS produced with a $4.76-\mathrm{mm}$ screen and amended with 25\% (v/v) peatmoss (PTS3; Premier Tech, Quebec, Canada); and 4) a mix composed of $80 \%$ peat and $20 \%$ perlite $(\mathrm{v} / \mathrm{v}$; PL). The PTSs selected for this experiment were chosen based on their range of physical properties (Jackson and Wright, 2008). Pine tree substrate was produced from 12-year-old loblolly pine trees $(\approx 25 \mathrm{~cm}$ in basal diameter) that were harvested at ground level, delimbed on 9 Apr. 2007 in Blackstone, VA, and chipped with bark intact on 8 Aug. 2007 with a Bandit Chipper (Model 200; Bandit Industries, Inc., Remus, MI). Wood chips were then hammer-milled on 8 Aug. 2007 to pass through either a 2.38- or 4.76$\mathrm{mm}$ screen. Peat-lite substrate was preplantamended with dolomitic lime at a rate of 3.6 $\mathrm{kg} \cdot \mathrm{m}^{-3}$ and calcium sulfate $\left(\mathrm{CaSO}_{4}\right)$ at a rate of $0.6 \mathrm{~kg} \cdot \mathrm{m}^{-3}$. Only PTS3 was incorporated with $1.8 \mathrm{~kg} \cdot \mathrm{m}^{-3}$ dolomitic lime as a result of the $25 \%$ peatmoss amendment. Neither PTS1 nor PTS2 was amended with lime as a result of the relatively inherent high $\mathrm{pH}(\approx 6.0)$ of freshly ground pine wood (Wright et al., 2008), but all PTSs were amended with 0.6 $\mathrm{kg} \cdot \mathrm{m}^{-3} \mathrm{CaSO}_{4}$ as Saunders et al. (2005) reported improved growth of herbaceous species when $\mathrm{CaSO}_{4}$ was incorporated.

On 16 Aug. 2007, single-rooted cuttings of 'Prestige' poinsettia (Ecke Ranch; Yoder Brothers, Inc., Barberton, $\mathrm{OH}$ ) were transplanted into 12 -cm-tall $\times 15$-cm-square (1.7-L) plastic containers filled with the four substrates. To stimulate branching, the apical growing point was removed on $30 \mathrm{Aug} .2007$ to leave $\approx 6$ nodes. Plants were fertilized at each irrigation with $250 \mathrm{~mL}$ (beaker-applied) of $100,200,300$, or $400 \mathrm{mg} \cdot \mathrm{L}^{-1} \mathrm{~N}$ made from Peters 20N-4.4P-16.6K Peat-Lite Special (The Scotts Co., Marysville, $\mathrm{OH}$ ) containing $12 \%$ nitrate $\left(\mathrm{NO}_{3}-\mathrm{N}\right)$ and $8 \%$ ammonium $\left(\mathrm{NH}_{4}-\mathrm{N}\right)$ until 2 Oct. 2007. From 2 Oct. until 10 Nov. 2007, plants were fertilized with the same $\mathrm{N}$ concentrations derived from Peters 15N-2.2P-20.75K Poinsettia Peat-Lite Special (The Scotts Co.) containing $11 \% \mathrm{NO}_{3}-\mathrm{N}$ and $4 \% \mathrm{NH}_{4}-\mathrm{N}$, respectively. Fertilizers were switched to lower the amount of $\mathrm{NH}_{4}-\mathrm{N}$ and increase the amount of $\mathrm{NO}_{3}-\mathrm{N}$ supplied to the crop as suggested by Ecke et al. (2004). Plants in all substrate treatments were irrigated and fertilized similarly. Plants were grown without growth regulators on raised benches in the Virginia Tech (Blacksburg, VA) Greenhouse Facility (glass-covered) with average day and night temperatures of 24 and $19^{\circ} \mathrm{C}$, respectively. Substrate solution was extracted using the pourthrough (PT) method (Wright, 1986) $1 \mathrm{~d}$ after potting (DAP) and then once per week for the first 4 weeks followed by every 2 weeks for the remainder of the experiment and analyzed for $\mathrm{pH}$ and electrical conductivity (EC) using a Hanna HI 9811 instrument (Hanna Instruments, Woonsocket, RI). Substrate solution extracted on 14 Sept. 2007 (30 DAP) and 26 Oct. 2007 (72 DAP) were frozen and later analyzed for $\mathrm{NO}_{3}-\mathrm{N}$ with an Orion ion selective electrode (Thermo Electron, Beverly, MA) on 17 Jan. 2008, and phosphorus (P) and potassium $(\mathrm{K})$ concentrations on 31 Jan. 2008 with a Spectro Ciros Vision ICP (Spectro Analytical Instrument, Mahwah, NJ). On 28 Sept. 2007 (42 DAP), growth index of each plant was determined using the following formula: [(height + widest width + perpendicular width) $\div 3$ ]. On 15 Nov. 2007 (94 DAP), final growth measurements were taken, including growth index (GI) and bract length (BL) of the five largest bracts on each of the two tallest stems (10 bracts total). On 15 Nov. 2007, plants (10 single-plant replications) were severed at the substrate surface, forced-air dried for $5 \mathrm{~d}$ at $65{ }^{\circ} \mathrm{C}$, and dry weights were recorded.

On 3 Dec. 2007, six uniform replications of poinsettias grown at the $300 \mathrm{mg} \cdot \mathrm{L}^{-1} \mathrm{~N}$ fertilizer rate in each of the substrates were selected to assess the postproduction time to 
wilting of poinsettia without irrigations in an indoor environment. Plants fertilized with $300 \mathrm{mg} \cdot \mathrm{L}^{-1} \mathrm{~N}$ were chosen as a result of the similar plant growth across all substrates at that fertilizer rate. Plants were irrigated with 250-mL applications of water three times over $8 \mathrm{~h}$ to maintain moisture content near $\mathrm{CC}$ for all substrates. After drainage, plants were moved from the greenhouse to a laboratory (to simulate interior home conditions) and randomly spaced on tables. Plants were maintained at $16 \mu \mathrm{mol} \cdot \mathrm{m}^{-2} \cdot \mathrm{s}^{-1}$ of irradiance from cool-white fluorescent lights for $10 \mathrm{~h}$ daily at $26 \pm 1{ }^{\circ} \mathrm{C}$. Plants were observed daily and monitored for wilting. When the first leaf on a plant began to droop, the day and time were recorded for that plant (Stage I). When all leaves on a plant wilted, the day and time were again recorded (Stage II).

For substrate physical properties determination, 25-L samples of all substrates were collected on 14 Aug. 2007. These substrates were taken from the same batch used to pot the poinsettias and therefore amended similarly. Substrate samples were air-dried for $2 \mathrm{~d}$ and then bagged and dry-stored for 14 weeks (the duration of the poinsettia experiment). Plastic containers $[12 \mathrm{~cm}$ tall $\times 15 \mathrm{~cm}$ wide (1.7-L)] were filled with PL, PTS1, and PTS2 on 14 Aug. 2007 and placed fallow on a greenhouse bench. Six replications of each substrate were fertilized with $300 \mathrm{mg} \cdot \mathrm{L}^{-1} \mathrm{~N}$ made from Peters 20N-4.4P-16.6K Peal-Lite Special (The Scotts Co.) containing 12\% nitrate $\left(\mathrm{NO}_{3}-\mathrm{N}\right)$ and $8 \%$ ammonium $\left(\mathrm{NH}_{4}-\mathrm{N}\right)$ until 12 Nov. 2007 (96 DAP). Containers were irrigated once weekly with $500 \mathrm{~mL}$ of fertilizer solution. Substrate shrinkage (centimeters) was determined by measuring the difference in substrate height (from the top of the containers to the substrate surface) at 1 DAP after the first irrigation and again at 96 DAP. At 96 DAP, two containers of each substrate were combined and prepared for physical property determination $(\mathrm{n}=3)$.

Physical properties, including $\mathrm{AS}, \mathrm{CC}$, total porosity (TP), and bulk density (BD), were determined on 10 Dec. 2007 on three replicate samples of each substrate from the initial dry-stored bagged samples and from the fallow samples fertilized in containers using the North Carolina State University Porometer Method (Fonteno et al., 1995). Particle size distribution of $150 \mathrm{~g}$ oven-dried samples of PL, PTS1, and PTS2 were determined with 14 sieves (ranging from greater than $6.3 \mathrm{~mm}$ to less than $0.06 \mathrm{~mm}$ ) plus a bottom pan (Table 1). Sieves and pan were shaken for $10 \mathrm{~min}$ with a RX-29 Ro-Tap sieve shaker (278 oscillations/min, 150 taps/ min; W.S. Tyler, Mentor, $\mathrm{OH}$ ) and the particle fractions retained on each sieve and the amount that passed through the smallest sieve and retained by the sieve pan was weighed.

The experimental design was completely randomized with four substrates, four fertilizer rates, and eight replications per substrate for a total of 128 plants. Data were tested using the analysis of variance procedures of SAS (Version 9.1; SAS Institute, Inc., Cary,

Table 1. Particle size distribution of peat-lite (PL) and pine tree substrates (PTS) produced with 2.36- and 4.76-mm hammer-mill screens ${ }^{2}$.

\begin{tabular}{|c|c|c|c|c|c|c|c|}
\hline \multirow{3}{*}{$\begin{array}{l}\text { Particle size } \\
(\mathrm{mm})\end{array}$} & \multicolumn{6}{|c|}{ Particle size distribution ( $\%$ of dry wt) } & \multirow{3}{*}{$\begin{array}{l}\text { Particle siz } \\
\text { range }^{\mathrm{w}}\end{array}$} \\
\hline & \multicolumn{2}{|c|}{$\mathrm{PL}^{\mathrm{y}}$} & \multicolumn{2}{|c|}{$\begin{array}{c}\text { PTS1 }^{\mathrm{x}} \\
\end{array}$} & \multicolumn{2}{|c|}{$\mathrm{PTS}^{\mathrm{x}}$} & \\
\hline & Mean & SD & Mean & SD & Mean & SD & \\
\hline$>2.0$ & 23.18 & 1.01 & 0.16 & 0.07 & 0.96 & 0.93 & Coarse \\
\hline $1.0-2.0$ & 20.89 & 0.10 & 15.29 & 2.53 & 36.98 & 2.11 & \\
\hline $0.5-1.0$ & 25.29 & 0.85 & 43.47 & 1.79 & 33.09 & 1.97 & Medium \\
\hline $0.25-0.5$ & 17.38 & 0.34 & 25.89 & 1.08 & 19.16 & 1.60 & \\
\hline $0.125-0.25$ & 10.29 & 0.54 & 12.64 & 0.84 & 8.69 & 0.68 & \\
\hline $0.63-0.125$ & 2.69 & 0.50 & 1.76 & 0.25 & 0.96 & 0.04 & Fine \\
\hline$<0.063$ & 0.36 & 0.08 & 0.80 & 0.13 & 0.22 & 0.10 & \\
\hline
\end{tabular}

${ }^{2}$ Values are means of three air-dried substrate samples.

${ }^{y} \mathrm{PL}$ composed of $80 \%$ peatmoss $/ 20 \%$ perlite (by volume).

xPTS produced from 12-year-old loblolly pine trees harvested at ground level, delimbed, chipped, and hammer-milled to pass through 2.38-mm screen (PTS1) or 4.76-mm screen (PTS2).

"Particle size range: coarse $2.0 \mathrm{~mm}$ or greater; medium less than $2.0 \mathrm{~mm}$ to $0.5 \mathrm{~mm}$ or greater; fine less than $0.5 \mathrm{~mm}$.

NC). Data were also subjected to regression analysis using SigmaPlot (Version 9.01; SPSS, Inc., Chicago, IL) with the exception that substrate physical properties were subjected to analysis of variance within the GLM procedure with treatment means separated by least significant difference analysis.

\section{Results and Discussion}

Particle size distribution. Peat-lite had the highest percentage of coarse particles (greater than $2.0 \mathrm{~mm} ; 23 \%$ ) attributable primarily to the aggregates and clumps found in peat and also as a result of the perlite particles present in this substrate (Table 1). The PTS2 had the next highest percentage of coarse particles (1\%) followed last by PTS1 $(0.2 \%)$. Particle size distribution between 2.0 and $0.5 \mathrm{~mm}$ was $46 \%$ in PL, $59 \%$ in PTS 1 , and $70 \%$ in PTS2. Percentage of fine particles (less than 0.5 $\mathrm{mm}$ ) was highest in PTS1 (41\%) followed by PL with $31 \%$ and PTS2 with $29 \%$ (Table 1 ). By grinding wood with the 2.76-mm screen (PTS1), there was a $24 \%$ increase in the amount of fines produced compared with grinding with the 4.76-mm screen (PTS2; Table 1).

Physical properties: initial. Total porosity was higher in all PTSs compared with PL and were within, or higher than, the upper limit of the recommended range of $50 \%$ to 85\% (Yeager et al., 2007; Table 2). Air space was high in all PTSs and within the recommended range $(10 \%$ to $30 \%$; Table 2$)$. Peatlite had the lowest percentage AS $(15 \%)$ but was within the recommended range. Bulk density was equal for all PTSs and the PL value was similar to the PTS2 value. Container capacity values for PTS1 and PTS3 were equal to PL; PTS1 and PTS3 CC values were higher than the PTS2 value. This is likely the result of the higher percentage of fine particles in PTS1 (Table 1), which are known to increase CC, and PTS3 is higher because of the water retention of the $25 \%$ peat component.

Physical properties: final (final data were not determined for PTS3 as a result of sample contamination during storage). Total porosity increased in PL and PTS1 after 14 weeks but did not change in PTS2, and all substrate TP values were above the upper limit of the recommended range ( $50 \%$ to $85 \%$; Table 2 ). Higher than recommended TP values (greater than $85 \%$ ) have been previously reported with several commercial wood substrates in Europe, including Cultifiber ${ }^{\circledR}(94 \%)$, Fibra$\operatorname{lur}^{\circledR}(96 \%)$, Hortifiber ${ }^{\circledR}(94 \%)$, Pietal ${ }^{\circledR}$ (93\%), and Toresa ${ }^{\circledR}(92 \%$ to $97 \%$; Gumy, 2001; Raviv and Lieth, 2008). Air space did not change for PTS2 but decreased in PL and PTS1. Air space for all substrates was within the recommended range (10\% to $30 \%)$ after 14 weeks. Bulk density for all substrates was below the suggested levels $(0.19$ to 0.70$)$ after 14 weeks. Container capacity values were equal in PL and PTS1 and were lowest in PTS2 (Table 2). All substrates increased $\mathrm{CC}$ after 14 weeks and were at or above the suggested range at the end of the experiment. Decreased AS and increased CC over time could be the result of the settling "nesting" of the particles in a substrate when the finer particles fit between larger particles as described by Bilderback and Lorscheider (1995) or as a result of substrate decomposition. This increase in $\mathrm{CC}$ and decrease in $\mathrm{AS}$ has been shown by Bohne and Gunther (1997) and Prasad and Chualain (2005) in response to changes in particle sizes of a substrate. Over time for PTSs, the changes in physical characteristics were minor and with the exception of TP were substantially the same as those in PL showing that PTS can maintain desirable physical properties throughout a short-term crop production period.

Shrinkage after 14 weeks was lowest in PTS2 (7\%) followed by PL (12\%) and PTS1 (13\%; Table 2). Less shrinkage with PTS2 is likely the result of the larger particle size compared with PTS1, which agrees with observations by Wang (1994) who reported less shrinkage of a coarse particle substrate derived from kenaf wood compared with a smaller-particle kenaf substrate. Conversely, the increased shrinkage observed in PL and PTS1 is likely the result of their high percentage of small particles (Table 1). Shrinkage is the result of either breakdown (microbial decomposition) of the substrate or by substrate 
Table 2. Initial and final (after 14 weeks in containers fertilized weekly with $300 \mathrm{mg} \cdot \mathrm{L}^{-1}$ nitrogen) physical properties of peat-lite (PL) and pine tree substrates $(\mathrm{PTS})^{\mathrm{z}}$.

\begin{tabular}{|c|c|c|c|c|c|c|c|c|c|c|c|c|c|}
\hline \multirow[b]{2}{*}{ Substrate } & \multicolumn{3}{|c|}{ Total porosity ${ }^{\mathrm{y}}(\% \mathrm{vol})$} & \multicolumn{3}{|c|}{ Air space ${ }^{\mathrm{x}}(\%$ vol $)$} & \multicolumn{3}{|c|}{ Bulk density $^{\mathrm{w}}\left(\mathrm{g} \cdot \mathrm{cm}^{-3}\right)$} & \multicolumn{3}{|c|}{ Container capacity ${ }^{\mathrm{v}}(\% \mathrm{vol})$} & \multirow{2}{*}{$\begin{array}{c}\text { Substrate } \\
\text { shrinkage }^{\mathrm{u}}(\%)\end{array}$} \\
\hline & Initial & Final & LSD & Initial & Final & LSD & Initial & Final & LSD & Initial & Final & LSD & \\
\hline$\overline{\mathrm{PL}^{\mathrm{t}}}$ & $80.6 b^{s}$ & $85.9 \mathrm{~b}$ & $3.5^{\mathrm{r}}$ & $15.0 \mathrm{c}$ & $13.0 \mathrm{c}$ & 1.9 & $0.16 \mathrm{a}$ & $0.18 \mathrm{a}$ & 0.02 & $65.6 \mathrm{a}$ & $72.9 \mathrm{a}$ & 4.8 & $11.9 \mathrm{a}$ \\
\hline $\mathrm{PTS}^{\mathrm{q}}$ & $86.7 \mathrm{a}$ & $90.0 \mathrm{a}$ & 2.4 & $22.1 \mathrm{~b}$ & $18.0 \mathrm{~b}$ & 1.5 & $0.14 \mathrm{~b}$ & $0.15 \mathrm{~b}$ & 0.01 & $64.6 \mathrm{a}$ & $72.0 \mathrm{a}$ & 3.0 & $12.7 \mathrm{a}$ \\
\hline PTS2q & $84.9 \mathrm{a}$ & $89.4 \mathrm{a}$ & 4.7 & $30.2 \mathrm{a}$ & $24.7 \mathrm{a}$ & 7.9 & $0.15 \mathrm{ab}$ & $0.16 \mathrm{~b}$ & 0.01 & $54.6 \mathrm{~b}$ & $64.9 \mathrm{~b}$ & 4.8 & $6.8 \mathrm{~b}$ \\
\hline PTS3 ${ }^{\text {qp }}$ & $86.5 \mathrm{a}$ & - & - & $21.4 \mathrm{~b}$ & - & - & $0.14 \mathrm{~b}$ & - & - & $65.9 \mathrm{a}$ & - & - & - \\
\hline Range $^{\circ}$ & \multicolumn{2}{|c|}{$50-85$} & - & \multicolumn{2}{|c|}{$10-30$} & - & \multicolumn{2}{|c|}{$0.19-0.70$} & - & \multicolumn{2}{|c|}{$45-65$} & - & 一 \\
\hline
\end{tabular}

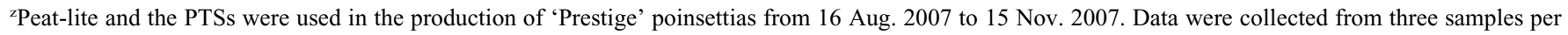
substrate and represented as means. Analysis performed using the North Carolina State University Porometer method (Fonteno et al., 1995).

${ }^{y}$ Total porosity is equal to container capacity + air space.

xAir space is the volume of water drained from the sample $\div$ volume of the sample.

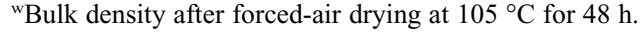

${ }^{\mathrm{v}}$ Container capacity is (wet weight - oven dry weight) $\div$ volume of the sample.

uShrinkage $=$ substrate height in container at $1 \mathrm{~d}$ after potting (DAP) - substrate height at 96 DAP.

'PL composed of $80 \%$ peatmoss $/ 20 \%$ perlite $(\mathrm{v} / \mathrm{v})$.

${ }^{\mathrm{s}}$ Means separated within columns (initial and final) by Duncan's multiple range test $(P \leq 0.05)$.

${ }^{\mathrm{r}}$ Means were separated within rows between initial and final substrate properties by least significant difference (LSD) at $P \leq 0.05$.

aPTS produced from 12-year-old loblolly pine trees harvested at ground level, delimbed, chipped, and hammer-milled to pass through 2.38-mm (PTS1) or 4.76-mm (PTS2) screens. PTS3 was produced with a 4.76- $\mathrm{mm}$ screen and amended with $25 \%$ peatmoss (by volume).

POnly initial physical properties were determined on this substrate.

${ }^{\circ}$ Suggested range for container substrates $=$ Best Management Practices recommended sufficiency ranges for physical properties of substrates used in general container production (Yeager et al., 2007).

settling and compression caused by gravity and water movement through the substrate during irrigations (Fonteno et al., 1981; Meinken and Fischer, 1997). When particles of different sizes are mixed, shrinkage of the final volume occurs, because small particles fill the pores located between the large particles (Bures et al., 1993; Nash and Pokorny, 1990).

Effects on poinsettia growth, floral quality, and postproduction time to wilting. Shoot dry weight increased in response to increasing fertilizer rate in each of the substrates (Table 3 ). There was a substrate $\times$ fertilizer rate response for shoot dry weight across substrates (Table 3 ). At the $100 \mathrm{mg} \cdot \mathrm{L}^{-1}$ $\mathrm{N}$ rate, shoot dry weight was higher in plants grown in PL than in all other substrates; shoot dry weight of plants grown in PTS1 and PTS3 were not different; and dry weight of plants grown in PTS2 was lowest (Table 3). At the $200 \mathrm{mg} \cdot \mathrm{L}^{-1} \mathrm{~N}$ rate, shoot dry weight was equal for PL, PTS1, and PTS3 with PTS2

being lowest. The $25 \%$ peat in PTS3 is likely responsible for the improved shoot dry weight at the 100 and $200 \mathrm{mg} \cdot \mathrm{L}^{-1} \mathrm{~N}$ fertilizer rates compared with PTS2 resulting from improved physical (Table 2) and chemical properties of the coarser PTS. Shoot dry weight at the $300 \mathrm{mg} \cdot \mathrm{L}^{-1} \mathrm{~N}$ rate was equal in all substrates. These growth results are the same as our preliminary study in 2005 and those reported by Wright et al. (2008), who showed that chrysanthemums require an additional $100 \mathrm{mg} \cdot \mathrm{L}^{-1} \mathrm{~N}$ when grown in $4.76 \mathrm{~mm}$ PTS (PTS2) to achieve comparable growth to plants grown in a peat substrate. The $300 \mathrm{mg} \cdot \mathrm{L}^{-1} \mathrm{~N}$ rate required for plants grown in PTS is within the recommended fertilizer range (200 to $300 \mathrm{mg} \cdot \mathrm{L}^{-1} \mathrm{~N}$ ) suggested for poinsettia growth (Ecke et al., 2004). Shoot dry weight at the $400 \mathrm{mg} \cdot \mathrm{L}^{-1}$ $\mathrm{N}$ rate was less for the PL-grown plants than plants grown in PTS1 and PTS3.

Decreased shoot dry weight of plants in $\mathrm{PL}$ at the $400 \mathrm{mg} \cdot \mathrm{L}^{-1} \mathrm{~N}$ rate may be in

Table 3. Shoot dry weight (g) of 'Prestige' poinsettias grown from 16 Aug. 2007 to 15 Nov. 2007 (94 d after planting) in either peat-lite (PL) or pine tree substrates (PTS) and fertilized with four rates of a $15 \mathrm{~N}-2.2 \mathrm{P}-20.75 \mathrm{~K}$ soluble fertilizer.

\begin{tabular}{|c|c|c|c|c|}
\hline \multirow{3}{*}{$\begin{array}{l}\text { Fertilizer rate } \\
\left(\mathrm{mg} \cdot \mathrm{L}^{-1}\right)^{\mathrm{z}}\end{array}$} & \multicolumn{4}{|c|}{ Shoot dry wt (g) } \\
\hline & \multicolumn{4}{|c|}{ Substrate } \\
\hline & $\mathrm{PL}^{\mathrm{y}}$ & PTS1 $^{x}$ & $\mathrm{PTS}^{\mathrm{x}}$ & PTS3 $^{\mathrm{x}}$ \\
\hline 100 & $20.6 \mathrm{a}^{\mathrm{w}}$ & $15.9 \mathrm{~b}$ & $11.0 \mathrm{c}$ & $14.1 \mathrm{~b}$ \\
\hline 200 & $35.8 \mathrm{a}$ & $36.6 \mathrm{a}$ & $27.9 \mathrm{~b}$ & $32.2 \mathrm{ab}$ \\
\hline 300 & $48.2 \mathrm{a}$ & $49.0 \mathrm{a}$ & $43.3 \mathrm{a}$ & $47.7 \mathrm{a}$ \\
\hline 400 & $37.3 \mathrm{~b}$ & $42.1 \mathrm{ab}$ & $40.0 \mathrm{~b}$ & $49.1 \mathrm{a}$ \\
\hline \multirow[t]{2}{*}{ Significance $^{v}$} & $\mathrm{~L}^{* * *}$ & $\mathrm{~L}^{* * *}$ & $\mathrm{~L}^{* * *}$ & $\mathrm{~L}^{* * *}$ \\
\hline & $\mathrm{Q}^{* * *}$ & $\mathrm{Q}^{* * *}$ & $\mathrm{Q}^{* * *}$ & Q*** \\
\hline$P$ values $^{\mathrm{u}}$ & \multicolumn{4}{|c|}{ Substrate $(\mathrm{S})=0.0065 ;$ fertilizer $(\mathrm{F})=\leq 0.0001 ; \mathrm{S} * \mathrm{~F}=0.0453$} \\
\hline \multicolumn{5}{|c|}{ 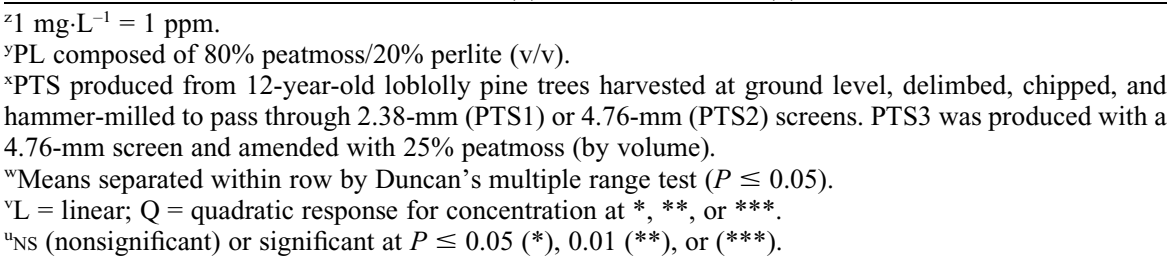 } \\
\hline
\end{tabular}

response to the low substrate $\mathrm{pH}$ level (4.8) or the high $\mathrm{EC}$ value $\left(3.7 \mathrm{dS} \cdot \mathrm{m}^{-3}\right)$ that was observed at that fertilizer rate (to be discussed later) and lower shoot dry weight for PTS2grown plants is likely the result of lower CC (Table 2). The increased microbial activity in PTS, reported by Jackson et al. (2008), and the resulting $\mathrm{N}$ immobilization in PTS (Jackson and Wright, 2007, 2008) is the likely reason for the additional fertilizer requirement in PTS for optimal plant growth. It is not believed that the absence of dolomitic lime in PTS1 and PTS2 (and therefore the additional calcium supplied by the lime to PL and PTS3) had any effect on plant growth in this experiment. Calcium concentrations in substrate solution were sufficient in all substrates at all fertilizer rates (data not shown) and therefore are negligible in the growth results. In addition, Saunders et al. (2005) and numerous unpublished studies by these authors have shown that increased calcium application to PTS (above the $0.6 \mathrm{~kg} \cdot \mathrm{m}^{-3}$ applied) does not increase plant growth in PTS.

Growth index at 42 DAP for PL-grown plants was not influenced by fertilizer rate, but GI did increase in response to fertilizer for plants in all PTSs (Table 4). Similar to shoot dry weight, GI was higher in PL-grown plants than the PTSs at the $100 \mathrm{mg} \cdot \mathrm{L}^{-1} \mathrm{~N}$ rate at 42 and 94 DAP, but as fertilizer rate increased, GI differences between substrates were few with the possible exception of PTS3 at 94 DAP. It is not understood why GI of PTS3-grown plants at 94 DAP did not equal the GI of PL-grown plants at the 200 and 300 $\mathrm{mg} \cdot \mathrm{L}^{-1} \mathrm{~N}$ rates like was shown at $42 \mathrm{DAP}$ and for shoot dry weight.

Bract length increased as fertilizer rate increased for all substrates (Table 5). Bract length was determined because bract size is an indicator of high-quality, visually appealing poinsettias. In general, with the exception of some minor discrepancies, BL was lowest in PTS2-grown plants and highest for PL, 
Table 4. Growth index $\mathrm{x}^{\mathrm{z}}$ of 'Prestige' poinsettias at $42 \mathrm{~d}$ after planting (DAP) and 94 DAP grown in either peat-lite (PL) or pine tree substrates (PTS) and fertilized with four rates of a $15 \mathrm{~N}-2.2 \mathrm{P}-20.75 \mathrm{~K}$ soluble fertilizer.

\begin{tabular}{|c|c|c|c|c|}
\hline \multirow{4}{*}{$\begin{array}{l}\text { Fertilizer rate } \\
\left(\mathrm{mg} \cdot \mathrm{L}^{-1}\right)^{\mathrm{w}}\end{array}$} & \multicolumn{4}{|c|}{ Growth index } \\
\hline & \multicolumn{4}{|c|}{ Substrate } \\
\hline & $\mathrm{PL}^{\mathrm{y}}$ & $\mathrm{PTS1}^{\mathrm{x}}$ & $\mathrm{PTS}^{\mathrm{x}}$ & $\mathrm{PTS3}^{\mathrm{x}}$ \\
\hline & \multicolumn{4}{|c|}{42 DAP } \\
\hline 100 & $28.5 \mathrm{a}^{\mathrm{v}}$ & $22.2 \mathrm{~b}$ & $17.7 \mathrm{c}$ & $20.2 \mathrm{~b}$ \\
\hline 200 & $27.9 \mathrm{ab}$ & $28.4 \mathrm{a}$ & $25.8 \mathrm{~b}$ & $27.4 \mathrm{ab}$ \\
\hline 300 & $29.3 \mathrm{a}$ & $29.6 \mathrm{a}$ & $28.9 \mathrm{a}$ & $29.7 \mathrm{a}$ \\
\hline 400 & $26.3 \mathrm{~b}$ & $27.4 \mathrm{ab}$ & $27.0 \mathrm{ab}$ & $30.1 \mathrm{a}$ \\
\hline \multirow[t]{2}{*}{ Significance $^{u}$} & L NS & $\mathrm{L}^{* *}$ & $\mathrm{~L}^{* * *}$ & $\mathrm{~L}^{* * *}$ \\
\hline & Q NS & $\mathrm{Q}^{* * *}$ & $\mathrm{Q}^{* * *}$ & $\mathrm{Q}^{* * *}$ \\
\hline$P$ valuest: & \multicolumn{4}{|c|}{ Substrate $(S)=0.0432 ;$ fertilizer $(F)=<0.0001 ; \mathrm{S} * \mathrm{~F}=0.0022$} \\
\hline
\end{tabular}

\section{Fertilizer rate}

\begin{tabular}{lcccr}
$\left(\mathrm{mg} \cdot \mathrm{L}^{-1}\right)$ & \multicolumn{3}{c}{$94 \mathrm{DAP}$} \\
\hline 100 & $41.2 \mathrm{a}$ & $37.8 \mathrm{~b}$ & $33.5 \mathrm{c}$ & $31.1 \mathrm{c}$ \\
200 & $49.0 \mathrm{a}$ & $46.1 \mathrm{~b}$ & $44.0 \mathrm{~b}$ & $40.4 \mathrm{c}$ \\
300 & $50.7 \mathrm{a}$ & $49.7 \mathrm{a}$ & $48.0 \mathrm{a}$ & $45.0 \mathrm{~b}$ \\
400 & $46.8 \mathrm{a}$ & $45.8 \mathrm{a}$ & $47.2 \mathrm{a}$ & $46.0 \mathrm{a}$ \\
Significance & $\mathrm{L}^{*}$ & $\mathrm{~L}^{* * *}$ & $\mathrm{~L}^{* * *}$ & $\mathrm{~L}^{* * *}$ \\
& $\mathrm{Q}^{* * *}$ & $\mathrm{Q}^{* * *}$ & $\mathrm{Q}^{* * *}$ & $\mathrm{Q}^{* * *}$ \\
$P$ values: & \multicolumn{2}{c}{ Substrate $(\mathrm{S})=\leq 0.0001 ;$ fertilizer $(\mathrm{F})=\leq 0.0001 ; \mathrm{S}^{*} \mathrm{~F}=0.0006$}
\end{tabular}

${ }^{\mathrm{z}}$ Growth index [(height + widest width + perpendicular width $) \div 3$ ] .

${ }^{y} \mathrm{PL}$ composed of $80 \%$ peatmoss $/ 20 \%$ perlite (by volume).

${ }^{x}$ PTS produced from 12-year-old loblolly pine trees harvested at ground level, delimbed, chipped, and hammer-milled to pass through 2.38-mm (PTS1) or 4.76-mm (PTS2) screens. PTS3 was produced with a 4.76-mm screen and amended with $25 \%$ peatmoss (by volume).

${ }^{\mathrm{w}} 1 \mathrm{mg} \cdot \mathrm{L}^{-1}=1 \mathrm{ppm}$.

'Means separated within row by Duncan's multiple range test $(P \leq 0.05)$

${ }^{\mathrm{u}} \mathrm{L}=$ linear; $\mathrm{Q}=$ quadratic response for concentration at $*, * *$, or $* * *$.

${ }^{\mathrm{t}} \mathrm{NS}$ (nonsignificant) or significant at $P \leq 0.05(*), 0.01(* *)$, or $0.001(* * *)$.

Table 5. Bract length (cm) of 'Prestige' poinsettias grown from 16 Aug. 2007 to 15 Nov. 2007 ( 94 d after planting) in either peat-lite (PL) or pine tree substrates (PTS) and fertilized with four rates of a $15 \mathrm{~N}-$ $2.2 \mathrm{P}-20.75 \mathrm{~K}$ soluble fertilizer.

\begin{tabular}{lcccr}
\hline & \multicolumn{4}{c}{ Bract length $(\mathrm{cm})$} \\
\cline { 2 - 5 } $\begin{array}{l}\text { Fertilizer rate } \\
\left(\mathrm{mg} \cdot \mathrm{L}^{-1}\right)^{\mathrm{x}}\end{array}$ & \multicolumn{4}{c}{ Substrate } \\
\cline { 2 - 5 } 100 & $\mathrm{PL}^{\mathrm{z}}$ & $\mathrm{PTS}^{\mathrm{y}}$ & $\mathrm{PTS}^{\mathrm{y}}$ & $\mathrm{PTS}^{\mathrm{y}}$ \\
200 & $12.1 \mathrm{a}^{\mathrm{w}}$ & $12.1 \mathrm{a}$ & $11.1 \mathrm{~b}$ & $12.6 \mathrm{a}$ \\
300 & $13.7 \mathrm{~b}$ & $13.4 \mathrm{~b}$ & $13.3 \mathrm{~b}$ & $15.0 \mathrm{a}$ \\
400 & $14.9 \mathrm{~b}$ & $15.5 \mathrm{a}$ & $14.3 \mathrm{c}$ & $15.9 \mathrm{a}$ \\
& $14.0 \mathrm{~b}$ & $15.3 \mathrm{a}$ & $13.9 \mathrm{~b}$ & $15.2 \mathrm{a}$ \\
Significance & $\mathrm{L}^{\mathrm{v}}$ & $\mathrm{L}^{* * *}$ & $\mathrm{~L}^{* * *}$ & $\mathrm{~L}^{* * *}$ \\
& $\mathrm{~L}^{* * *}$ & $\mathrm{Q}^{* * *}$ & $\mathrm{Q}^{* * *}$ & $\mathrm{Q}^{* * *}$ \\
& \multicolumn{2}{c}{ values: } & Substrate $(\mathrm{S})=\leq 0.0001 ;$ fertilizer $(\mathrm{F})=\leq 0.0001 ; \mathrm{S} * \mathrm{~F}=0.0016$
\end{tabular}

${ }^{2}$ PL composed of $80 \%$ peatmoss $/ 20 \%$ perlite (by volume).

y PTS produced from 12-year-old loblolly pine trees harvested at ground level, delimbed, chipped, and hammer-milled to pass through 2.38-mm (PTS1) or 4.76-mm (PTS2) screens. PTS3 was produced with a $4.76-\mathrm{mm}$ screen and amended with $25 \%$ peatmoss (by volume).

${ }^{\mathrm{x}} 1 \mathrm{mg} \cdot \mathrm{L}^{-1}=1 \mathrm{ppm}$.

${ }^{\text {w} M e a n s ~ s e p a r a t e d ~ w i t h i n ~ r o w ~ b y ~ D u n c a n ' s ~ m u l t i p l e ~ r a n g e ~ t e s t ~}(P \leq 0.05)$.

${ }^{\mathrm{v}} \mathrm{L}=$ linear; $\mathrm{Q}=$ quadratic response for concentration at $*, * *$, or $* * *$.

"NS (nonsignificant) or significant at $P \leq 0.05(*), 0.01\left(^{* *}\right)$, or $0.001\left(^{* * *}\right)$.

PTS1, and PTS3-grown plants. The reason for increased BL in PL, PTS1, and PTS3 is likely (like with shoot dry weight) the result of higher $\mathrm{CC}$ and thus higher water and nutrient retention compared with PTS2 (Table 2).

Postproduction time to wilting (Stage I and Stage II) occurred first in PTS2-grown plants with no differences in the drying/ wilting time among plants grown in PL, PTS1, or PTS3 (Table 6). The earliness of the PTS2-grown plants to wilt is most likely the result of the lower $\mathrm{CC}$ of that substrate compared with the others (Table 2). The
Table 6. Postproduction days required for two stages of wilting of poinsettias grown in peatlite (PL) and three pine tree substrates (PTS) at a $300 \mathrm{mg} \cdot \mathrm{L}^{-1}$ nitrogen fertilizer rate ${ }^{\mathrm{z}}$.

\begin{tabular}{|c|c|c|c|c|}
\hline \multirow{3}{*}{$\begin{array}{l}\text { Wilting } \\
\text { stage }\end{array}$} & \multicolumn{4}{|c|}{ Day to wilting } \\
\hline & \multicolumn{4}{|c|}{ Substrate } \\
\hline & $\mathrm{PL}^{y}$ & PTS1 $^{x}$ & $\mathrm{PTS}^{\mathrm{x}}$ & PTS \\
\hline Stage IV & $7.9 \mathrm{a}^{\mathrm{w}}$ & $7.9 \mathrm{a}$ & $5.6 \mathrm{~b}$ & \\
\hline Stage II ${ }^{\mathrm{u}}$ & $11.0 \mathrm{a}$ & $10.5 \mathrm{a}$ & $8.4 \mathrm{~b}$ & 10.8 \\
\hline
\end{tabular}

Plants were stored in an indoor environment (temperature of $26{ }^{\circ} \mathrm{C}$, respectively). Data collected on six plants in each substrate.

${ }^{\mathrm{y}} \mathrm{PL}$ composed of $80 \%$ peatmoss $/ 20 \%$ perlite (by volume).

xPTS produced from 12-year-old loblolly pine trees harvested at ground level, delimbed, chipped, and hammer-milled to pass through 2.38-mm (PTS1) or 4.76-mm (PTS2) screens. PTS3 was produced with a $4.76-\mathrm{mm}$ screen and amended with $25 \%$ peatmoss (by volume).

wMeans separated within row by Duncan's multiple range test $(P \leq 0.05)$

${ }^{v}$ Stage I was recoded when wilting first began (leaf droop).

uStage II was recorded when all leaves were completely wilted against the stem.

compared with PL and decreased as fertilizer rate increased (Table 7). Substrate solution EC values increased with increasing fertilizer rate and at any particular fertilizer rate, levels were higher in PL than the three PTSs (Table 7), showing that higher fertilizer rates were required for all PTSs compared with PL to achieve comparable substrate EC levels. Lower substrate solution EC and higher $\mathrm{pH}$ in PTS compared with PL has been reported previously by Wright et al. (2008).

There was a substrate $\times$ fertilizer rate response for $\mathrm{P}$ and $\mathrm{K}$ in the substrate solution, but not for $\mathrm{NO}_{3}-\mathrm{N}$. Nitrate concentrations increased as fertilizer rates increased in all substrates and were generally higher in PL at each fertilizer rate than in the PTSs. Similar to the EC levels and $\mathrm{NO}_{3}-\mathrm{N}$ concentrations previously discussed, $\mathrm{P}$ concentrations were higher in PL (except at the $100 \mathrm{mg} \cdot \mathrm{L}^{-1} \mathrm{~N}$ rate) at each fertilizer rate compared with the three PTSs (Table 7). Conversely, substrate solution $\mathrm{K}$ concentrations were higher at each fertilizer rate in all PTSs than in PL, which has been previously reported by Wright et al. (2008) during the production of chrysanthemums. Substrate solution sampled on 26 Oct. showed similar responses and trends to these reported for 14 Sept. and therefore are not shown.

Lower $\mathrm{NO}_{3}-\mathrm{N}$ concentrations in substrate solution of PTS is likely a result of microbial immobilization of $\mathrm{NO}_{3}-\mathrm{N}$ as reported by Jackson and Wright (2008). The reason for lower substrate solution P concentrations in all PTSs may be two-fold. First, it has been shown that microbial immobilization of $\mathrm{P}$ occurs in wood-based substrates (Handreck, 1996), reducing the amount of soluble $P$ in solution. Second, it has been reported that $\mathrm{P}$ retention is higher in wood-based substrates (resulting in less water-extractable P) compared with peat as a result of exchange sites on the internal surfaces of the wood particles (Brown and Pokorny, 1977). Higher substrate 
Table 7. pH, electrical conductivity (EC), and substrate nutrient concentrations collected on 14 Sept. 2007 from 'Prestige' poinsettia grown in either peat-lite (PL) or pine tree substrates (PTS) and fertilized with four rates of a $15 \mathrm{~N}-2.2 \mathrm{P}-20.75 \mathrm{~K}$ soluble fertilizer ${ }^{2}$.

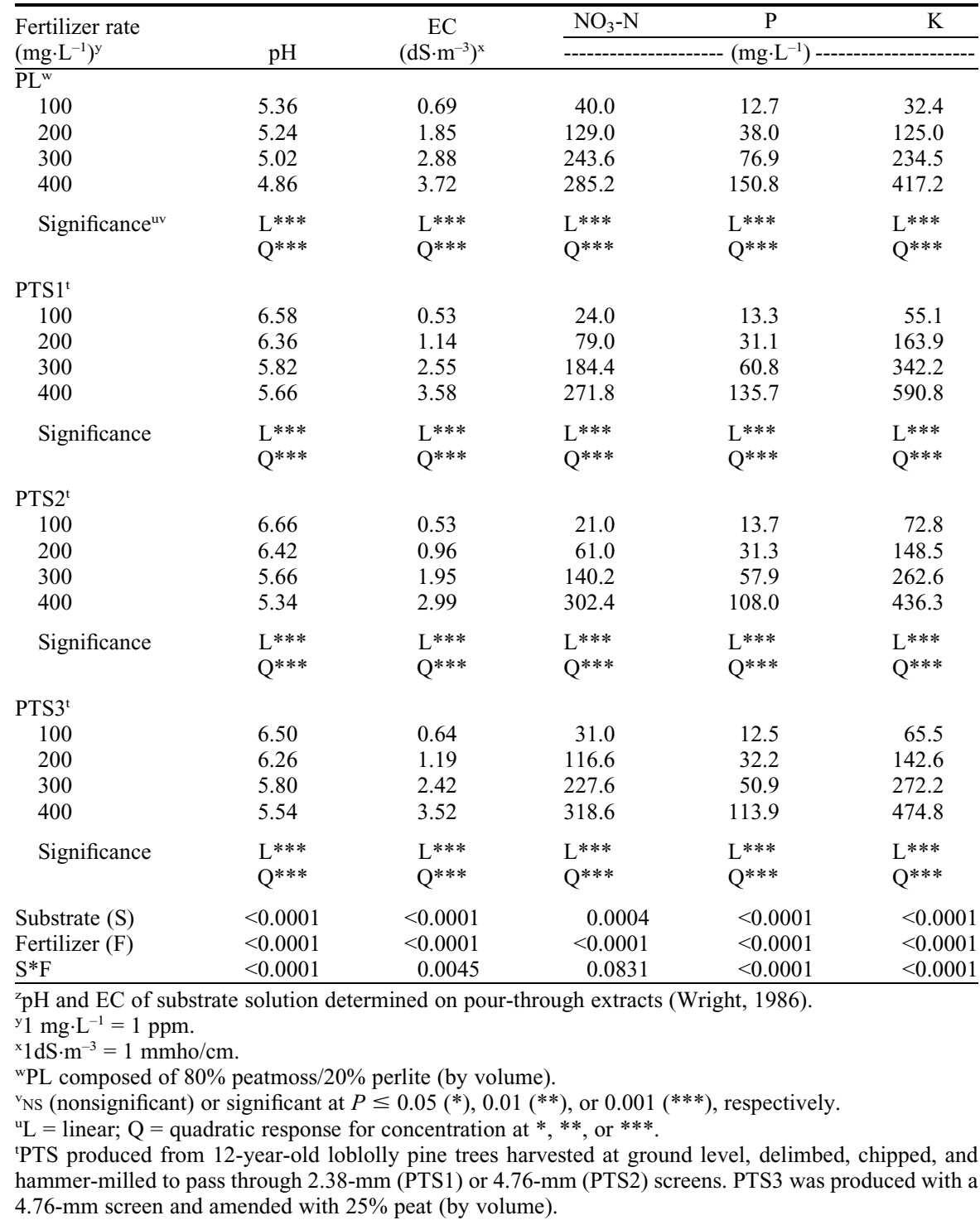

solution $\mathrm{K}$ in all PTSs is likely the result of higher concentrations of $\mathrm{K}$ present in fresh (noncomposted) wood compared with K concentrations found in peat, which has been observed by these authors (unpublished results) and also reported by Prasad (1980).

\section{Conclusions}

Results from this experiment indicate that $100 \%$ PTS can be a successful greenhouse substrate with similar plant growth and shrinkage as a traditional peat substrate if additional fertilizer is supplied or if substrate physical properties are adjusted to be similar to those of peat. We also observed the apparent benefits that the addition of peatmoss can have to a coarse PTS to improve plant growth and postproduction shelf life as a result of improved physical properties.

Because PTS is produced from freshly harvested trees, it, unlike many compostbased substrates, is a clean material free from undesirable components such as glass, metal, future. One way to offset potential competition for pine wood is to establish pine plantations specifically for PTS production by individual growers or by a consortium of growers in areas throughout the southeast to guarantee sufficient wood sources in the future.

\section{Literature Cited}

Aendekerk, T.G.L. 2001. Decomposition of peat substrates in relation to physical properties and growth of Skimmia. Acta Hort. 548:261268.

Bilderback, T.E. and M.R. Lorscheider. 1995. Physical properties of double-processed pine bark: Effects on rooting. Acta Hort. 401:77-83.

Bohne, H. and C. Gunther. 1997. Physical properties of peat determined with different methods. Acta Hort. 450:271-276.

Boyer, C.R., G.B. Fain, C.H. Gilliam, T.V. Gallagher, H.A. Torbert, and J.L. Sibley. 2008. Clean chip residual: A substrate component for growing annuals. HortTechnology 18:423-432

Browder, J.F., J. Smithson, B.E. Jackson, and R.D. Wright. 2006. Pine chips: Peat substrate ratios affect plant growth. Proc. Southern Nursery Assoc. Research Conf. 51:98-99.

Brown, E.F. and F.A. Pokorny. 1977. Potassium distribution and retention in pine bark and sand media. HortScience 12:343-344.

Bures, S., F.A. Pokorny, D.P. Landau, M.A. Farmer, and A.M. Ferrenberg. 1993. Shrinkage, porosity characterization, and computer simulation of horticultural substrates. Acta Hort. 342:229-234.

Carlile, W.R. 2004. Growing media and the environmental lobby in the UK 1997-2001. Acta Hort. 644:107-113.

Clark, D. 2008. The wise use of peat in horticulture. Acta Hort. 779:161-164.

Criley, R.A. and R.T. Watanabe. 1974. Response of chrysanthemum in four soilless media. HortScience 9:385-386.

Ecke P., Jr., J.E. Faust, J. Williams, and A. Higgins. 2004. The poinsettia manual. Paul Ecke Poinsettias, Encinitas, CA.

Fain, G.B., C.H. Gilliam, J.L. Sibley, and C.R. Boyer. 2008. Wholetree substrate and fertilizer rate in production of greenhouse-grown petunia (Petunia $\times$ hybrida Vilm.) and marigold (Tagetes patula L.). HortScience 43:700-705.

weed seeds, pathogens, and heavy metals. The ability to grind PTS to various particle sizes to achieve desired physical properties (AS and CC) excludes the need for additional amendments (perlite, vermiculite, PB, and so on) that are required for commercial peat substrates. The low BD of PTS could be important for shipping considerations of these substrates, because weight increases shipping costs.

Loblolly pine is native to the southeastern United States and can be found in close proximity to nursery and greenhouse operations. Pine tree substrate can be produced in these areas, minimizing transportation costs to growers. It should also be mentioned that the use of wood materials (including loblolly pine trees) are being developed as fuel sources (i.e., wood pellets) as alternative energy sources. Competition for loblolly pine trees for fuel wood should be considered because it relates to the cost of pine chips and ultimately the production cost of PTS as it is developed and used commercially in the

Fischer, P., E. Meinken, and F. Kalthoff. 1993. Holzfaserstoffe im test (Woodfibre in test). Gärtnerbörse Gartenwelt 26:1220-1222.

Floriculture and Nursery Crops Yearbook. 2007. Economic research service, U.S. Dept. Agri., FLO-2007. 1 July 2008. <http://www.ers.usda. gov/publications/flo/2007/09Sep/FLO2007.pdf>.

Fonteno, W.C., D.K. Cassel, and R.A. Larson. 1981. Physical properties of three container media and their effect on poinsettia growth. J. Amer. Soc. Hort. Sci. 106:736-741.

Fonteno, W.C., C.T. Hardin, and J.P. Brewster. 1995. Procedures for determining physical properties of horticultural substrates using the NCSU Porometer. Horticultural Substrates Laboratory, North Carolina State University.

Gerber, T., F. Steinbacher, and B. Hauser. 1999. Wood fiber substrate for cultivating Pelargonium hortum L.-Biophysical examinations and plant growth. J. App. Bot. 73:217-221.

Gruda, N. and W.H. Schnitzler. 1999. Influence of wood fiber substrates and nitrogen application rates on the growth of tomato transplants. Adv. Hort. Sci. 13:20-24.

HortScience Vol. 43(7) December 2008 
Gumy, N. 2001. Toresa ${ }^{\circledR}$ and other wood fiber products: Advantages and drawbacks when used in growing media, p. 39-46. Proc. Intl. Peat Symp., Peat in horticulture: Peat and its alternatives in growing media.

Handreck, K.A. 1996. Phosphorus immobilization in wood waste-based potting media. Commun. Soil Sci. Plant Anal. 27:2295-2314.

Hicklenton, P.R. 1983. Flowering, vegetative growth and mineral nutrition of pot chrysanthemums in sawdust and peat-lite media. Scientia Hort. 21:189-197.

Hidalgo, P.R. and R.L. Harkess. 2002. Earthworm castings as a substrate for poinsettia production. HortScience 37:304-308.

Holmes, S. 2008. Growing media developments in the UK over the last twenty years. Acta Hort. (in press).

Jackson, B.E. and R.D. Wright. 2007. Pine tree substrate: Fertility requirements. Proc. Southern Nursery Assoc. Research Conf. 52: 58-61.

Jackson, B.E. and R.D. Wright. 2008. Pine tree substrate: An alternative and renewable growing media for horticulture crop production. Acta Hort. (in press).

Jackson, B.E., R.D. Wright, J.F. Browder, J.R. Harris, and A.X. Niemiera. 2008. Effect of fertilizer rate on growth of azalea and holly in pine bark and pine tree substrates. HortScience 43:1561-1568.

Ku, C.S.M., J.C. Bouwkamp, and F.R. Gouin. 1998. Effects of compost source and timing of fertigation initiation on growth of potted poinsettia. Compost Sci. 6:57-66.

Lang, H.J. 1997. Growth of poinsettia in potting media amended with ground kenaf stem core. HortScience 32:483-484.

Meinken, E. and P. Fischer. 1997. Sackungsverhalten von Holzfasern. Gärtnerbörse 9:494496.
Nash, M.A. and F.A. Pokorny. 1990. Shrinkage of selected two-component container media. HortScience 25:930-931.

Nelson, P.V. 2003. Greenhouse operation and management. 6th Ed. Prentice Hall, Englewood Cliffs, NJ.

Papafotiou, M., M. Phsyalou, G. Kargas, I. Chatzipavlidis, and J. Chronopoulos. 2004. Olive-mill wastes compost as growing medium component for the production of poinsettia. Scientia Hort. 102:167-175.

Prasad, M. 1980. Retention of nutrients by peats and wood wastes. Scientia Hort. 12:203-209.

Prasad, M. and D.N. Chualain. 2005. Relationship between particle size and air space of growing media. Acta Hort. 648:161-166.

Raviv, M. and J.H. Lieth. 2008. Soilless culture: Theory and practice. Elsevier Publishing, San Diego, CA.

Riviere, L.M., P. Morel, J.C. Michel, and S. Charpentier. 2008. Growing media in French horticulture. Acta Hort. 779:33-38.

Robertson, R.A. 1993. Peat, horticulture and environment. Biodivers. Conserv. 2:541-547.

Saunders, T., J.F. Browder, B.E. Jackson, and R.D. Wright. 2006. Particle size of a pine chips substrate affects plant growth. Proc. Southern Nursery Assoc. Research Conf. 51:46-48.

Saunders, T.N., R.D. Wright, and J.F. Browder. 2005. Chipped pine logs: A potential substrate for nursery and greenhouse crops. Proc. Southern Nursery Assn. Res. Conf. 50:112-114.

Schilling, R. 1999. Toresa ${ }^{\circledR}$. Comb. Proc. Intl. Plant Prop. Soc. 49:410-412.

Schmilewski, G. 2008. The role of peat in assuring the quality of growing media. Mires and Peat 3:1-8.

Scott, E.G. and B.C. Bearce. 1972. A hardwoodbark-sawdust compost for greenhouse pot flower production. Forest Prod. J. 22:3639.

Starck, J.R. and K. Lukaszuk. 1991. Effect of fertilizer nitrogen and potassium upon yield and quality of carnations growth in peat and sawdust. Acta Hort. 294:289-296.

Still, S., J.B. Gartner, and T.D. Hughes. 1972. Effect of sawdust age and nitrogen application on chrysanthemums grown in white oak sawdust media. Forest Prod. J. 22:111114.

Wang, Y.T. 1994. Using ground kenaf stem core as a major component of container media. J. Amer. Soc. Hort. Sci. 119:931-935.

Wang, Y.T. and T.M. Blessington. 1990. Growth and interior performance of poinsettia in media containing composted cotton burrs. HortScience 25:407-408.

Webber C.L., III, J. Whitworth, and J. Dole. 1999. Kenaf (Hibiscus cannabinus L.) core as a containerized growth medium component. Ind. Crops Prod. 10:97-105.

Worrall, R.J. 1981. Comparison of composted hardwood and peat-based media for the production of seedlings, foliage, and flowering plants. Scientia Hort. 15:311-319.

Wright, R.D. 1986. The pourthrough nutrient extraction procedure. HortScience 21:227229.

Wright, R.D. and J.F. Browder. 2005. Chipped pine logs: A potential substrate for greenhouse and nursery crops. HortScience 40:15131515.

Wright, R.D., J.F. Browder, and B.E. Jackson. 2006. Ground pine chips as a substrate for container-grown woody nursery crops. J. Environ. Hort. 24:181-184.

Wright, R.D., B.E. Jackson, J.F. Browder, and J.G. Latimer. 2008. Growth of chrysanthemum in ground pine trees requires additional fertilizer. HortTechnology 18:111-115.

Yeager, T.H., D.C. Fare, J. Lea-Cox, J. Ruter, T.E. Bilderback, C.H. Gilliam, A.X. Niemiera, S.L. Warren, T.E. Whitwell, R.D. Wright, and K.M Tilt. 2007. Best management practices: Guide for producing container-grown plants. 2nd Ed. Southern Nurserymen's Assoc, Marietta, GA. 